\title{
User satisfaction in educational institutions libraries: A case study of advanced institute of education
}

\author{
Subhash Chand \\ Librarian, Advanced Institute of Technology \& Management, Palwal, Haryana, India \\ *Corresponding Author: Subhash Chand \\ Email: subhashaitm@gmail.com
}

\begin{abstract}
Libraries and their services worldwide have undergone a signification change due to the application of Information Technology in all types of library functions like automated catalogue, online retrieval of information, access of online and off line databases etc. Today we are living in an age of information. Survival is not so much a matter of doing as of knowing. Large amount of information is being generated even moment. Information is a vital and necessary product of modern society and is most basic need to teachers, students, research scholars, scientists, thinkers and academicians as well as public to update their knowledge. The library is a wide resource to provide information to all kind of users. The present study suggested the use and satisfaction level of the users of Advanced Institute of Education Aurangabad, Palwal, Haryana (India).
\end{abstract}

Keywords: AIE, E-resources, E - journals, SBBET, ICT.

\section{Introduction}

The library is the most effective and economics medium for spread of education and dissemination of information. Education is a process and from childhood to old age every one continuously passes through this process. In the whole life the human passes through or receives education in two forms: formal education and informal education. The library plays vital role by helping the citizen pursue both forms of education. Research is the life - blood of modern society; as our economic standard of living, our culture and our age of progress depend upon it. Research has been changed significantly over the past four decades. The changing patterns of the research reflect developments in the intellectual thought that have created new academic disciplines and areas of research. In the past the information is present in printed form only, after introduction of ICT in libraries the existing and new information will be provided to the users in the form of "Electronically" i.e., e-resources. Epublication is the publication of any kind of information on any form of electronic media. E-journals have become major resources in scholarly research which is the simple electronic representation of journals. As we know that the users are the key person in any information system. The success of any information system depends on how best the system design is based on a close and accurate understanding of the users. User satisfaction studies are also part of user studies as these are based on users. The performance of a library can be judged on the basis of the extent of satisfaction it provides to its users. Hence, there is a need to conduct the use and user satisfaction studies to assess the satisfaction of users with the services and facilities provided by the library. This type of studies is also necessary to know the difference in satisfaction among the different categories of users.

\section{Objectives}

The objectives of the study are:

1. To identify the frequency of visits to the library.
2. To identify the frequency of time spent in the library per week.

3. To find out the level of satisfaction of students with regard to the following library collection.

4. To assess the level of satisfaction of students with E resources.

5. To find the level of satisfaction of students with regard to the library Services.

6. To find the level of satisfaction of students with regard to the library issues.

7. To find out the information sources and services that exits to satisfy the information needs of the students.

\section{Scope of the Study}

The scope of this study is to confirmed the analysis of use and satisfaction of the library collection, services and facilities by D.Ed.; B.Ed. and M. Ed. students in various disciplines of Advanced Institute of Education, Aurangabad, Palwal, Haryana(India) during 2012-2013, namely;

1. Diploma in Education (D.Ed./JBT)

2. Bachelor of Education. (B.Ed.)

3. Master of Education.(M. Ed.)

\section{Advanced Institute of Education}

Advanced Institute of Education is situated on NH-2, DelhiMathura Road, at Aurangabad Village, District Palwal in Haryana. The Institution established by Shri Bankey Bihary Educational Trust(SBBET) Faridabad under Advanced Educational Institutions. Advanced Educational Institutions is a group of Institution. This group of institutions has following institutions:

1. Advanced Institute of Technology \& Management

2. Advanced College of Technology \& Management

3. Advanced Institute of Education

4. Advanced Institute of Pharmacy

Advanced Institute of Education in 2007. The institute having a grade from NAAC and affiliated from M D U Rohtak and accredited by UGC, New Delhi. The college offers three 
courses in education one is PG level one undergraduate (UG) and one Diploma course. The institute satisfying the norms stipulated by the affiliating university M D U, Rohtak and UGC/NCTE. The institute has a well furnished library-cuminformation centre. The institute provides good computing facilities to its UG, PG and diploma students.

\section{Methodology}

This is a survey research in which sample survey has been done based on the status, strength and course in the Advanced Institute of Education. In order to study use and satisfaction of the library services, collection, and facilities in Advanced Institute of Education, Aurangabad Palwal District, Haryana has been chosen. There are one undergraduate course, one Postgraduate and one diploma course in this institute. Hence the researchers selecting from all three levels. Owing to the constraints of time and other reasons, we have selected 30 users from each course. One hundred and questionnaires were distributed randomly and all 100 filled questionnaires collected from them by giving sufficient time to fill up the questionnaires. If any of the students was willing to fill up the questionnaire immediately, we waited till it was filled up. We did not insist on the users mentioned their names on the questionnaires if they were unwilling to do so. Every effort was made by us to get reliable and accurate data from students.

\section{About Library-cum Information Centre}

The Library of Advanced Institute of Education is a good library. It has a rich collection of books, journals, magazines, CDs, audio and video cassettes, project reports with field work in soft as well as hard copies, dictionaries, encyclopedias, survey reports, reference books and newspapers. The institute pays good attention for the development of library and spends a reasonably good amount of money for the procurement of the above. The activities of all sections of library are computerized and interconnected all four libraries to each other with a single server through LAN. Library has a digital library section with 10 computers. The current holdings of the library:
Table 1: Library Information Resources

\begin{tabular}{|c|l|l|}
\hline S. No. & Information resources & Numbers \\
\hline 1 & Books & 14359 \\
\hline 2 & Total titles & 1200 \\
\hline 3 & Journals & 20 \\
\hline 4 & Online journals & 250 \\
\hline 5 & Back volumes of journals & 520 \\
\hline 6 & Dissertations & 850 \\
\hline 7 & Audio and video cassettes & 77 \\
\hline 8 & CD-ROM's & 487 \\
\hline 9 & Survey reports & 36 \\
\hline 10 & Encyclopedias & 54 \\
\hline 12 & Magazine & 10 \\
\hline 13 & News paper & 7 \\
\hline
\end{tabular}

Visits of users in the Library: The frequency of users according to their frequency of visiting the library is shown in table 1 ,

Table 2: Users frequency of visit to the library

\begin{tabular}{|c|l|c|c|}
\hline & Frequency of visit & $\begin{array}{c}\text { No. of } \\
\text { users }\end{array}$ & Percentage \\
\hline 1 & Every day & 60 & 60.00 \\
\hline 2 & Once a week & 12 & 12.00 \\
\hline 3 & More than once in a week & 28 & 28.00 \\
\hline & Total & $\mathbf{1 0 0}$ & $\mathbf{1 0 0 . 0 0}$ \\
\hline
\end{tabular}

Time Spent in Library: The distribution of users accordingly to their time spent in the library is shown as.

Table 3: Time Spent in Library

\begin{tabular}{|c|l|c|c|}
\hline S. No. & Time Spent & $\begin{array}{c}\text { No. of } \\
\text { Users }\end{array}$ & Percentage \\
\hline 1 & Less than one hours & 65 & 65.00 \\
\hline 2 & One hour & 15 & 15.00 \\
\hline 3 & Two hours & 11 & 11.00 \\
\hline 4 & Three hours & 6 & 6.00 \\
\hline 5 & More than three hours & 3 & 3.00 \\
\hline & Total & $\mathbf{1 0 0}$ & $\mathbf{1 0 0 . 0 0}$ \\
\hline
\end{tabular}

Table 4: Use of Library Collection

\begin{tabular}{|c|l|c|c|}
\hline S. No. & Library resources & No. of Users & Percentage \\
\hline 1 & Text Books & 57 & 57.00 \\
\hline 2 & Reference Books & 8 & 8.00 \\
\hline 3 & Journals(Online + Print) & 18 & 18.00 \\
\hline 4 & Desertations & 8 & 8.00 \\
\hline 5 & News Papers & 9 & 9.00 \\
\hline & Total & $\mathbf{1 0 0}$ & $\mathbf{1 0 0 . 0 0}$ \\
\hline
\end{tabular}

Table 5: Use of e-resources

\begin{tabular}{|c|l|c|}
\hline S. No. & E - resources & Users in Percentage \\
\hline 1 & Online Journals & 22.00 \\
\hline 2 & Online Databases & 25.00 \\
\hline 3 & CD-ROM Databases & 6.00 \\
\hline 4 & Audio visual materials & 5.00 \\
\hline 5 & OPAC & 32 \\
\hline
\end{tabular}




\begin{tabular}{|c|l|c|}
\hline 6 & College Website & 10 \\
\hline & Total & $\mathbf{1 0 0}$ \\
\hline
\end{tabular}

The distribution of users accordingly to their relative level of satisfaction with library services, total weight age, means weight age and ranks are given in Table 6.

Table 7: User's satisfaction with Library Services

\begin{tabular}{|c|c|c|c|c|c|c|c|c|c|c|c|c|c|}
\hline \multirow[t]{3}{*}{ Library Services } & \multicolumn{10}{|c|}{ Level of Satisfaction } & \multirow{3}{*}{$\begin{array}{c}\text { Total } \\
\text { Weightage }\end{array}$} & \multirow{3}{*}{$\begin{array}{c}\text { Mean } \\
\text { Weightage }\end{array}$} & \multirow[t]{3}{*}{ Rank } \\
\hline & \multicolumn{2}{|c|}{ NS } & \multicolumn{2}{|c|}{ NMS } & \multicolumn{2}{|c|}{ PS } & \multicolumn{2}{|c|}{ FS } & \multicolumn{2}{|c|}{$\mathrm{AS}$} & & & \\
\hline & $\mathrm{N}$ & $\mathrm{W}$ & $\mathrm{N}$ & $\mathrm{W}$ & $\mathrm{N}$ & $\mathrm{W}$ & $\mathrm{N}$ & $\mathrm{W}$ & $\mathrm{N}$ & $\mathrm{W}$ & & & \\
\hline Book Lending Services & 2 & 0 & 4 & 1 & 3 & 2 & 20 & 3 & 71 & 4 & 354 & 35.4 & 1 \\
\hline Reference Service & 1 & 0 & 5 & 1 & 8 & 2 & 25 & 3 & 61 & 4 & 340 & 34.0 & 2 \\
\hline Reprographic Service & 4 & 0 & 6 & 1 & 12 & 2 & 36 & 3 & 42 & 4 & 306 & 30.6 & 3 \\
\hline ILL Services & 10 & 0 & 7 & 1 & 16 & 2 & 29 & 3 & 38 & 4 & 278 & 27.8 & 4 \\
\hline Bibliographic Service & 16 & 0 & 10 & 1 & 30 & 2 & 25 & 3 & 19 & 4 & 221 & 22.10 & 5 \\
\hline
\end{tabular}

It is evident from Table 6 that the users are more satisfied with the book lending service as compared to other library services provided by the library and it has got first rank. It is followed by Reference service, Reprographic service, ILL service and Bibliographic service which got the ranks 2, 3, 4 and 5 respectively.

Satisfaction from Library Staff Behaviour: The distribution of users according to their level of satisfaction with library staff behaviour is shown in Table 7 .

Table 8: User's satisfaction with the Behavior Library Staff

\begin{tabular}{|c|l|c|c|}
\hline S. No. & Level of Behaviours & No. of users & Percentage \\
\hline 1 & Excellent & 62 & 62 \\
\hline 2 & Good & 18 & 18 \\
\hline 3 & Fair & 16 & 16 \\
\hline 4 & Average & 4 & 4 \\
\hline & Total & $\mathbf{1 0 0}$ & $\mathbf{1 0 0 . 0 0}$ \\
\hline
\end{tabular}

It is evident from table 8 that the majority of the users (62\%) indicated that the library staff behavior was excellent. It is also evident from the table that $18 \%$ are good, $16 \%$ are fair and remaining $4 \%$ are average in regard and pleasant.

\section{Conclusion and Suggestions}

1. The majority $(60 \%)$ of the users visit the library every day.

2. Only (3\%) of the users have been using the library for more than three hours, $6 \%$ user's used the library three hours daily, $11 \%$ user's used the library for two hours in a day, $15 \%$ user's used the library for only one hour and $65 \%$ user's used the library only for less than one hour i.e. for books issue and return or news paper and magazines reading only.

3. Most of the users mainly use Textbooks and Journals as compared to other print resources.

4. Most of the users are using OPAC and online databases.

5. Most of the users are satisfied with the book lending services compared to other library services provided by the library. Users are least satisfied with the ILL services however three more libraries and membership of Delnet (M. No. - IM 3786) are available in Advanced Educational Institutions, campus.

6. Most of the users are satisfied with the reading space, comfortable furniture, ACs, drinking water and other facilities provided by the library.

7. The majority of the users $(62 \%)$ have responded that the library staff behavior is excellent.

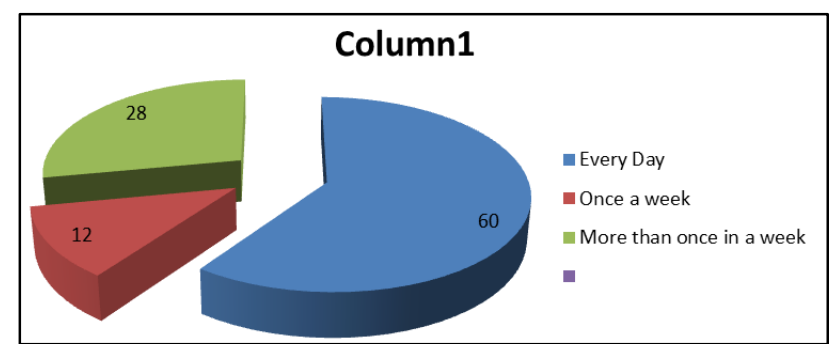

Fig.

\section{Suggestions}

The following suggestions are made by the investigators on the basis of analysis of the data and suggestion from users.

1. Some of the users have complained that books on the shelves are not arranged according to the classified order. Hence, proper steps should be taken for shelf rectification on a regular basis. 
2. The core periodicals for each department are to be decided on the basis of user's survey and only then should they subscribe.

3. The library authority should improve the ILL and Bibliographic service.

4. Most of user's of final classes want information regarding employment. So library authority pays attention for the same.

\section{Source of Funding}

None.

\section{Conflict of Interest}

None.

\section{References}

1. Ahmad S. Computer in library management. New Delhi: APH Publishing Corporation. 2005.

2. Kumar G. Defiling the Concept of Information Needs. New Delhi: Vikas Publishing House. 1990.

3. Prasad H.N. Information Needs and Users. Varansi: Indian Bibliographic Centre.1992

4. Sridhar MS. Information Seeking Behavior of Scientist and Engineering: A Case Study of Indian Space Technologist. New Delhi: Concept Publishing Co.1995.

5. Satija MP. Digital Information Systems and Services. IASLIC Bull. 2003;48(1):10-3.

6. Schemet J. R. ed. Encyclopedia of Communication and Information. New York: Gale Group.2002.

7. Kumar R. User Satisfaction in Engineering College Libraries.(In Collection Development and Management in Libraries and Information Centers in Digital Scenario). New Delhi: SSDN Publisher \& Distributors.2003.

8. Obcleaba EL. User satisfaction with library resources and services in Nigerian Agai. Res. Inst. Lib.Philosophy and Practies. pp. 1-15.2011 [ http://unllib.url.edu./lpp/]
9. Rajbala, Bajpai R.P. Use of internet and www among the students in faculty of Business management Manav Rachana Internetional University, Faridabad. Prof.jrl. of Lib. \& Inf. Tech. 2011;1:133-7.

10. Singh N. Use of e-resources and user's satisfaction in academic libraries. Jri Lib Inf Tech 20117(1):84-9.

11. Schaffner, B.L. Electronic resources: A wolf in sheep's clothing. College \& research Libraries, 2001;62(3):239-49.

12. Sharma C. Use and Impact of E-Resources at Guru Gobind Singh Indraprastha Management institutes library (India): A Case Study. Electronic J Acad Special Libr 2009;10(1).

13. Sharma, C. K. Research Methodology. Shree Publication: New Delhi.2000.

14. Sharma H.P. Moving beyond library automation. Role of eresources in academic library. University News. 2008;46(34):610.

15. Shokeen A, kaushik, SK. Information seeking behavior of social scientists of Haryana Universities. Library Herald, 2002;40(1):8-11.

16. Siebenberg, T.R., Galbraith, B., \& Brady E.E. Print verses Electronic journals use in three Sci/Tech disciplines: what's going on here?. Coll Res Libr 2004;65(5):162-8.

17. Singh VK. E-resource management. Semi. Procgs.Mumbai: Tata Memorial Hospital, pp. 1002-8.2010.

18. Sinha AK. Digital library and e-learning: challenges for a knowledge society; trends and future in the digital network environment. Int Libr Mov 2010;32(3):126-41.

19. Smith E.T. Changes in faculty reading behaviors: The impact Electronic journals on university of Georgia. J Acad Libr 29(3):162-8.

How to cite: Chand S. User satisfaction in educational institutions libraries: A case study of advanced institute of education. IP Indian J Libr Sci Inf Techno 2020;5(1):8-11. 